\title{
First DNA evidence on the occurrence of Pacific bluefin tuna, Thunnus orientalis in northern Philippine waters
}

\author{
Katreena P. Sarmiento ${ }^{1}$, Minerva Fatimae H. Ventolero', Rafael V. Ramiscal ${ }^{2}$, William S. Dela Cruz ${ }^{3}$ \\ and Mudjekeewis D. Santos ${ }^{1 *}$
}

\begin{abstract}
Background: Pacific bluefin tuna (Thunnus orientalis) spawning adults, juveniles and larvae are all reported to occur in areas between Philippine Sea and Japan Sea. However, no DNA evidence has been generated to support this.

Context and purpose of the study: In this study, Pacific bluefin tuna caught North of Polilio Island in the Philippine Pacific Seaboard, was identified through DNA barcoding using mitochondrial DNA D-loop region and cytochrome oxidase 1 gene.

Findings: The results show clustering of Philippine-caught bluefin tuna D-loop and CO1 sequences with published reference sequences for $T$. orientalis and supported by pairwise distances $<0.034$.
\end{abstract}

Conclusion: This study provides the first DNA evidence on the occurrence of T. orientalis in Philippine waters.

Keywords: Philippines, Thunnus orientalis, Pacific bluefin tuna, D-loop, Cytochrome oxidase 1

\section{Findings Introduction}

Pacific bluefin tuna Thunnus orientalis, (Temminck \& Schlegel, 1843) is considered as one of the most commercially important tuna species, highly priced reaching up to 100,000 US dollars per piece (Volpe 2005). The International Scientific Committee for Tuna and Tunalike Species in the North Pacific Ocean (ISC) indicated that overfishing of $T$. orientalis is happening and the stock is overfished based on several biological reference points commonly used by fisheries managers, hence it is placed as Vulnerable on the International Union for Conservation of Nature (IUCN) Red List Category \& Criteria and the current population trend is declared as Decreasing (Collette et al. 2014).

Pacific bluefin tuna, mainly distributed in the Northern Pacific Ocean, is known to be epipelagic found in

\footnotetext{
* Correspondence: mudjiesantos@gmail.com

${ }^{1}$ Genetic Fingerprinting Laboratory, National Fisheries Research and Development Institute, Room 601 Corporate 101 Bldg, Mother Ignacia Avenue, Quezon City 1103, Philippines

Full list of author information is available at the end of the article
}

temperate ocean (Ashida et al. 2015; Collette et al. 2014). They are usually found in waters of Japan, Korea, Guam, China, Papua New Guinea, and Taiwan (Collette et al. 2014). Tagging studies revealed that the movement pattern of $T$. orientalis is divided into two phases, residency and travelling. It was observed that Pacific bluefin tuna remain in areas of the East China Sea particularly in waters of east coast of Choshi, east coast of Hokkaido in the Western Pacific Ocean, Southern California, and Baja California, which are the four recognized major fishing grounds of Pacific bluefin tuna (Itoh et al. 2003).

Lewis (2012) suggested that quantities of juvenile Pacific Bluefin tuna $T$. orientalis may regularly occur in northern Philippine waters based on anecdotal reports and seasonal catch reports of adult spawning bluefin tuna by Taiwanese longliners. Particularly, actual landbased survey conducted in June 2005 yielded circumstantial evidence on the presence of juvenile Pacific bluefin tuna (1-6 kgs) in the waters of Cagayan Province from March to April. Moreover, the spawning grounds of $T$. orientalis were reported to occur from 
April to June at the area between Philippines and Ryukyu Islands in the North-western Pacific Ocean and juvenile $T$. orientalis are eventually transported near the Japan coastline by the Kuroshio Current (Itoh et al. 2003; Tanaka et al. 2006). Finally, IUCN listed Philippines as one of the countries where $T$. orientalis might occur (Collette et al. 2014).

While it is generally accepted that Pacific bluefin tuna, $T$. orientalis occur in northern Philippine waters, there has been no DNA analysis, which is considered a direct evidence of species identification, done thus far to support this. Here, we present the first DNA evidence to support the identification of a large tuna caught North of Polilio Island, Luzon as Pacific bluefin tuna $T$. orientalis.

\section{Materials and methods}

On May 16, 2015, a large tuna, initially identified by the fishermen as "bluefin tuna" (Fig. 1) was caught off North of Polilio Island by a hook and line fishing boat (FB PRINCE JIAN) based in Barangay Dinahican, Infanta, Quezon, Philippines. The boat captain was Mr. John Jay P. Paje Jr. and the fisherman who caught the "bluefin tuna" was Mr. Rojon Gian. Specific coordinates where the tuna was caught were

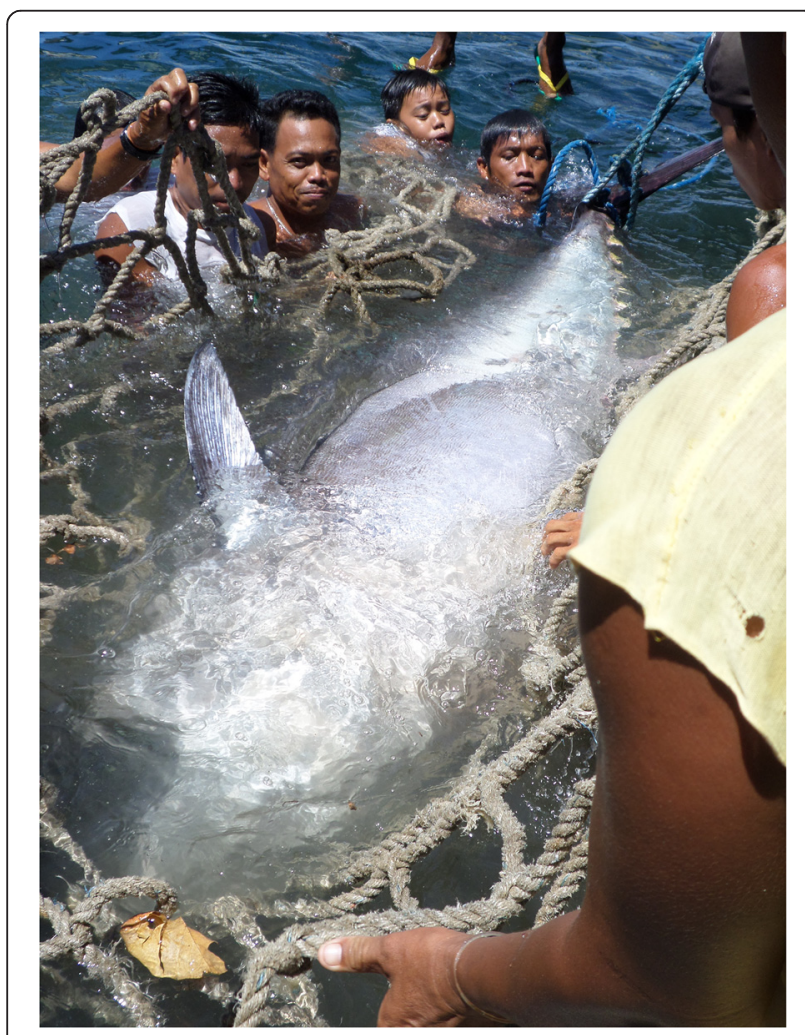

Fig. 1 Philippine Bluefin Tuna caught on May 16, 2015 in the Philippines recorded at $15^{\circ} 23.570 \mathrm{~N}, 121^{\circ} 59.868 \mathrm{E}$ (Fig. 2). The fish was delivered to the Malabon fish port and was recorded with a weight of approximately $300 \mathrm{~kg}$ and girth of $206 \mathrm{~cm}$. Further information on sample collection is indicated in Additional file 1: Tables S1 and S2. Fin sample from the "bluefin tuna" (Additional file 1: Figure S1) was delivered by Ms. Ellaine Garvilles of NFRDI to the NFRDI-Genetic Fingerprinting Laboratory (GFL) last July 29, 2015 for DNA-based identification.

Genomic DNA from the fin sample was extracted using DNeasy Blood \& Tissue Kit (QIAGEN) following the manufacturer's guidelines. Genetic markers, mitochondrial DNA fragment covering the 5'variable portion of the control region (D-loop) and cytochrome oxidase 1 (CO1), are considered as efficient and powerful tool for identification of fish species including tunas, hence these were used in this study (Ward et al. 2005; Paine et al. 2007; Kunal et al. 2013). The $\sim 600$ bp fragment of D-loop was amplified using the primers CB3R420 (5'-CCCCCTAAC TCCCAAAGCTAGG-3') and 12Sar430 (GCCTGCG GGGCTTTCTAGGGCC-3') (Santos et al. 2010). The reaction mixture for amplification of $\mathrm{CO} 1 \mathrm{had}$ a final volume of $26 \mu \mathrm{L}$ containing $2 \mu \mathrm{L}$ of template DNA in $1 x$ PCR Buffer and reagents with final concentration as follows: $0.2 \mathrm{mM}$ dNTPs, $2.4 \mathrm{mM} \mathrm{MgCl}_{2}$, $0.8 \mu \mathrm{M}$ each primers, 1 unit Taq polymerase (KAPA Biosystems), and ultrapure $\mathrm{dd}_{2} \mathrm{O}$. Tubes containing PCR mix were subjected to the conditions as follows: initial denaturation at $94{ }^{\circ} \mathrm{C}$ for $5 \mathrm{~min}$; 38 cycles of denaturation at $94{ }^{\circ} \mathrm{C}$ for $1 \mathrm{~min}$, annealing at $50{ }^{\circ} \mathrm{C}$ for $1 \mathrm{~min}$, extension at $72{ }^{\circ} \mathrm{C}$ for $1 \mathrm{~min}$; and final denaturation at $72{ }^{\circ} \mathrm{C}$ for $5 \mathrm{~min}$. On the other hand, the $\sim 650 \mathrm{bp}$ fragment of CO1 was amplified using the primers VF2_t1 (5'-TGTAAAACGACGGCCAGTC AACCAACCACAAAGACATTGGCAC-3'), FishF2_t1 (5'-TGTAAAACGACGGCCAGTCGACTAATCATAA AGATATCGGCAC-3'), FishR2_t1 (5'-CAGGAAACA GCTATGACACTTCAGGGTGACCGAAGAATCAG AA-3'), and Fr1d_t1 (5'-CAGGAAACAGCTATGACA CCTCAGGGTGTCCGAARAAYCARAA-3') (Ivanova et al. 2007). The reaction mixture for amplification of CO1 had a final volume of $26 \mu \mathrm{L}$ containing $2 \mu \mathrm{L}$ of template DNA in $1 \mathrm{x}$ PCR Buffer and reagents with final concentration as follows: $0.2 \mathrm{mM}$ dNTPs, $2.4 \mathrm{mM} \mathrm{MgCl}_{2}, 0.8 \mu \mathrm{M}$ each primers, 1 unit Taq polymerase (KAPA Biosystems), and ultrapure $\mathrm{dd}_{2} \mathrm{O}$. Tubes containing PCR mix were subjected to the conditions as follows: initial denaturation at $94{ }^{\circ} \mathrm{C}$ for $2 \mathrm{~min} ; 38$ cycles of denaturation at $94{ }^{\circ} \mathrm{C}$ for $30 \mathrm{~s}$, annealing at $52{ }^{\circ} \mathrm{C}$ for $40 \mathrm{~s}$, extension at $72{ }^{\circ} \mathrm{C}$ for $1 \mathrm{~min}$; and final denaturation at $72{ }^{\circ} \mathrm{C}$ for $10 \mathrm{~min}$. Positive amplicons were outsourced to Macrogen Inc. (Korea) for sequencing. 


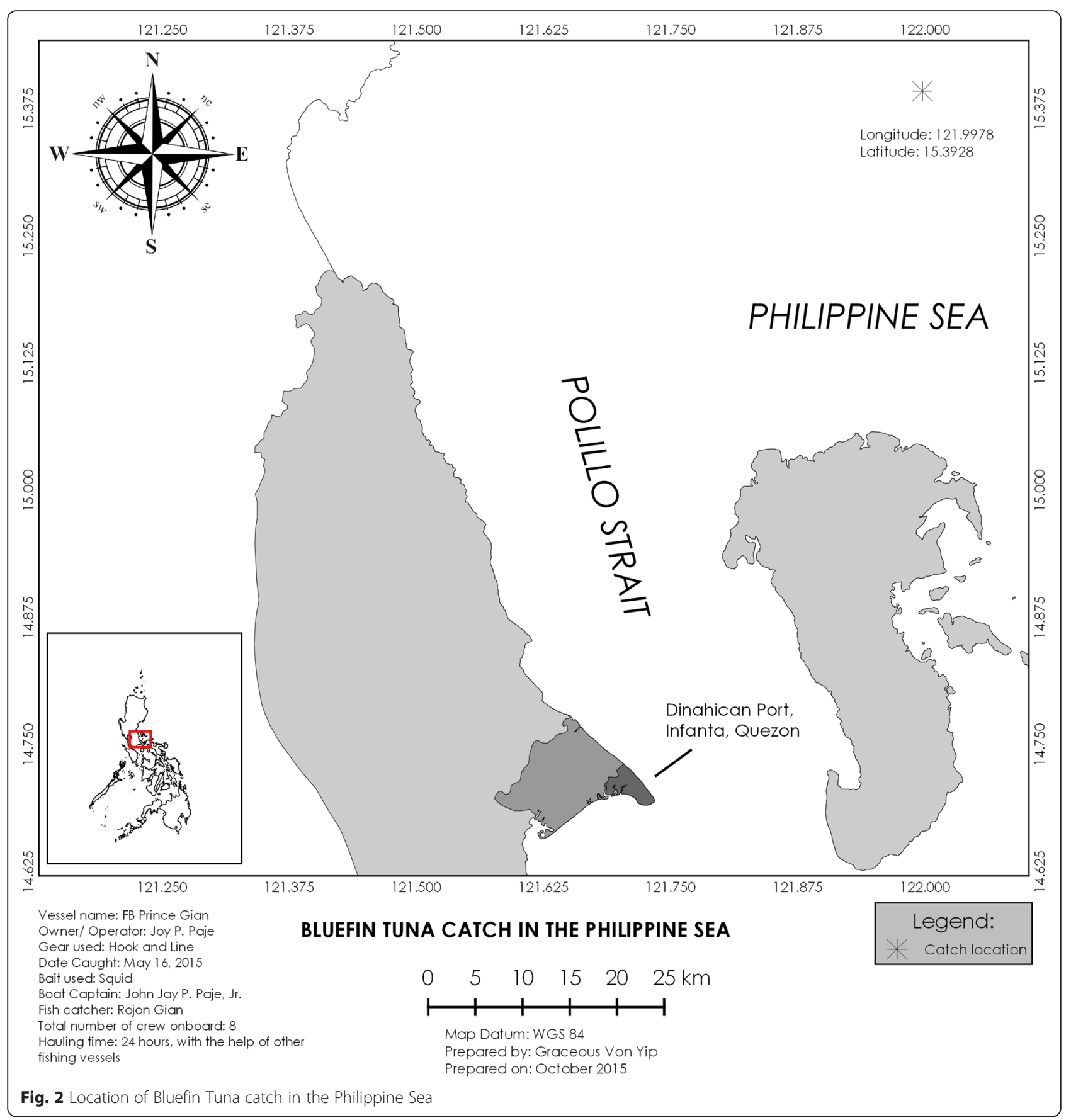

Generated D-loop and CO1 sequences were initially aligned and edited using Geneious 6.1.8 software. Consensus sequences were compared to those in GenBank using Basic Local Alignment Tool (BLAST), and CO1 and D-loop GenBank sequences (http://www.ncbi.nlm. nih.gov/genbank/) with identity $>90 \%$ and with published reports were used along with the sequences from this study in subsequent alignments using Molecular Evolutionary Genetics Analysis (MEGA) 6.0 (Tamura et al. 2013). ClustalW method was used for aligning DNA sequences together with the reference sequence. Specifically, genetic identification was inferred using Neighbor-Joining (NJ) method (Saitou \& Nei 1987) based on the Tamura 3-parameter (Tamura 1992) and Kimura 2-parameter (K2P) model (Kimura 1980) for D-loop and CO1 sequence analysis, correspondingly, with 500 bootstrap replications. The percentage of replicate trees in which the associated taxa clustered 
together in the bootstrap test, wherein values above $70 \%$ were considered reliable (Hillis and Bull 1993), was shown next to the branches (Felsenstein 1985). Divergence between sequences in the units of base substitutions per site was also analysed. All positions containing gaps and missing data were eliminated. Dloop and CO1 sequence from Katsuwonus pelamis and T. tonggol, respectively, were used as the root because these are members of the most closely related genus.

\section{Results and discussion}

Analysis of the generated D-loop sequence (GenBank accession no: KU058180.1) and partial CO1 sequence (GenBank accession no: KU058179.1) from the Philippine "bluefin tuna" using BLAST search showed $99 \%$ and $100 \%$ similarity, respectively, with published reference sequences for $T$. orientalis. The D-loop analysis involved 27 nucleotide sequences having 248 positions in the final dataset while $\mathrm{CO} 1$ analysis involved 24 nucleotide sequences having 536 positions in the final dataset.
For D-loop sequence analysis, the phylogenetic tree (Fig. 3) inferred from Neighbour Joining method using Tamura 3-parameter model shows that the obtained D-loop sequence from the Philippine "bluefin tuna" belonged to the same clade as $T$. orientalis, supported by a significant bootstrap value of 100 . Similar findings were concluded for the CO1 sequence analysis, wherein the phylogenetic tree (Fig. 4) inferred from Neighbour Joining method using Kimura 2-parameter model shows that the obtained CO1 sequence for the Philippine bluefin tuna clustered with $T$. orientalis.

In addition to this, computed average genetic distances among the D-loop (Table 1) and CO1 (Table 2) sequences also validated the identity of the Philippine bluefin tuna as $T$. orientalis with mean genetic distances occurring at 0.034 and 0.000 , for D-loop and CO1, respectively. These values of nucleotide differences strengthen positive identification of the Philippine "bluefin tuna" as T. orientalis. Multiple alignment of Philippine bluefin tuna D-loop and CO1 sequences with

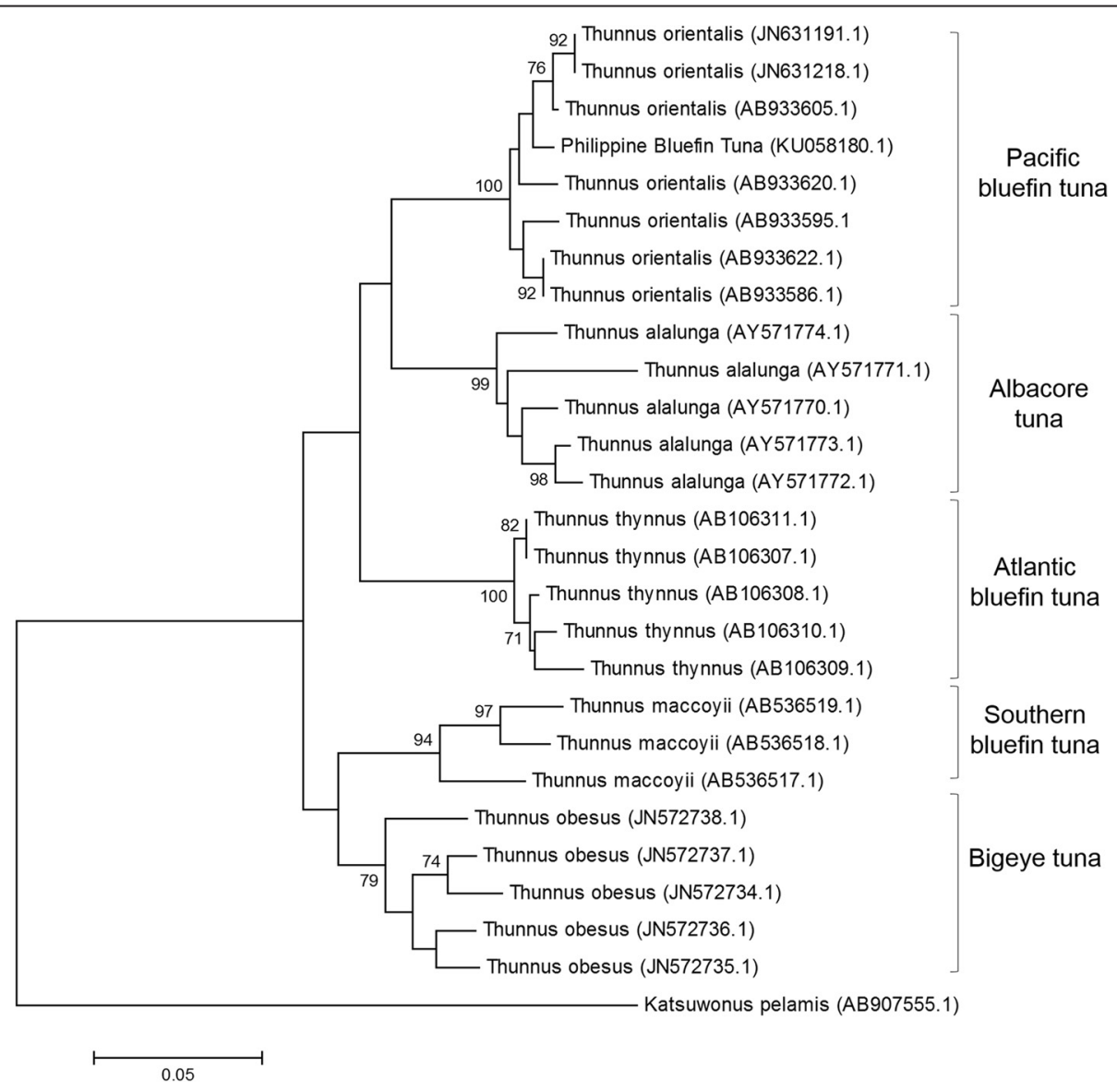

Fig. 3 Neighbour Joining Tree of D-loop sequences from Philippine Bluefin Tuna and reference sequences using the Tamura 3-parameter model. All reference sequences were obtained from GenBank with their accession numbers indicated within the parentheses 


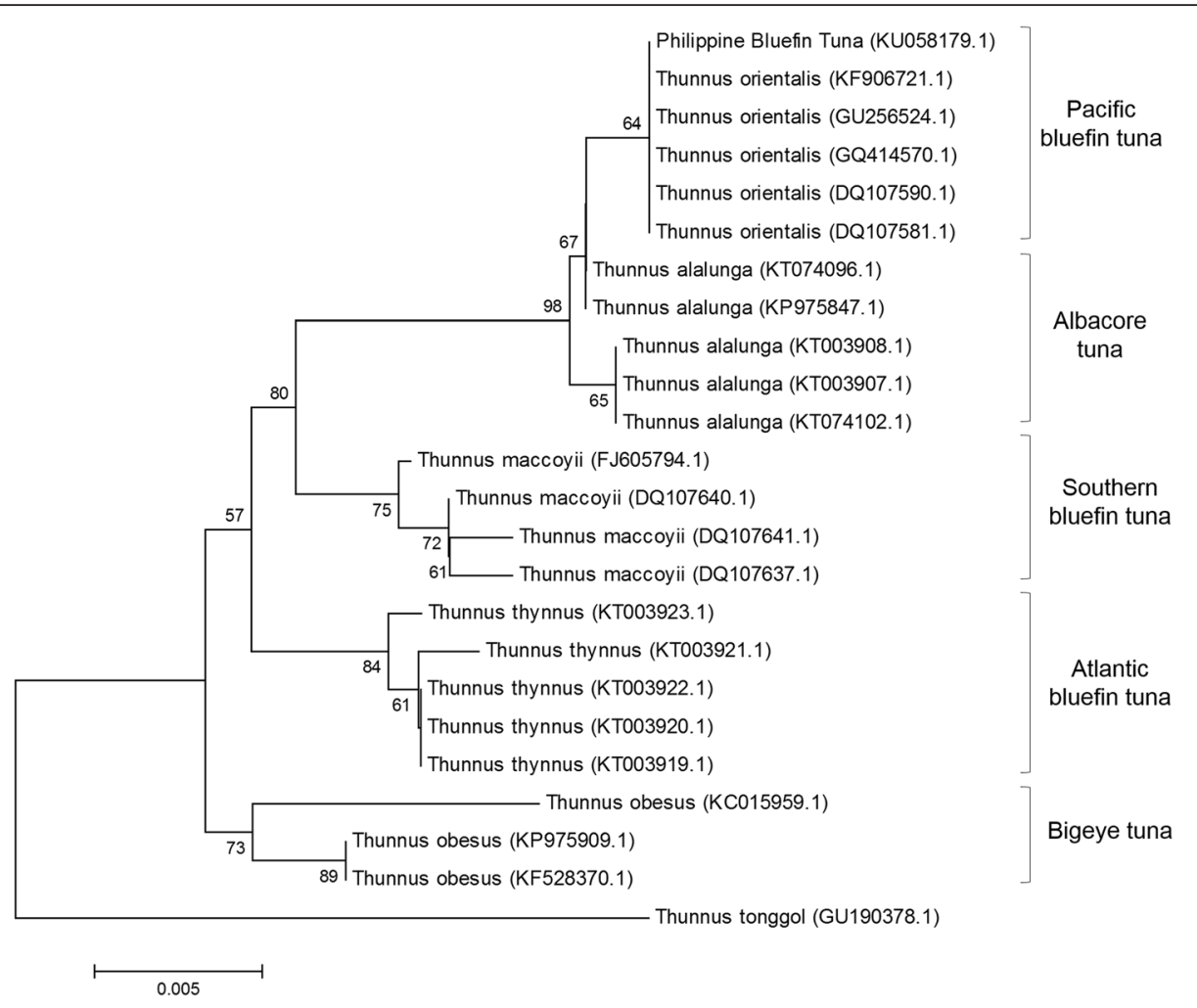

Fig. 4 Neighbour Joining Tree of CO1 sequences from Philippine Bluefin Tuna and reference sequences using the Kimura 2-parameter model. All reference sequences were obtained from GenBank with their accession numbers indicated within the parentheses

reference sequences are shown in Additional file 1: Figure S2 and S3, respectively.

The region of mtDNA control region D-loop showed high accuracy in distinguishing among tuna species particularly yellowfin (T. albacares) and bigeye (T. obesus) tunas (Pedrosa Gerasmio et al. 2012). On the other hand, the efficiency of $\mathrm{CO} 1$ as marker for differentiating tuna species was previously considered problematic (Viñas \& Tudela 2009). In this study, Dloop marker coupled with $\mathrm{CO} 1$ served positive identification of $T$. orientalis.

The present study confirms the presence of the Pacific bluefin tuna, $T$. orientalis in northern Philippine waters using DNA analysis and Lewis (2012), Collette et al.
(2014) and other researchers on the occurrence of Pacific bluefin tuna in northern Philippines.

Such identification add to the diversity of various tuna species recorded in the country. Moreover, it should support the previous proposal of the Comprehensive National Fisheries Industry Development Plan (CNFIDP) that considers T. orientalis as one of the species which could contribute to the sustainability of the commercial fisheries sub-sector in the Philippines. The confirmation of the existence of $T$. orientalis in Philippine waters highlights now the important role of the Philippines in conserving and sustaining this commercially important but vulnerable tuna species together with other range states.

Table 1 Average pairwise genetic distances between D-loop sequences of Philippine Bluefin tuna and reference species

\begin{tabular}{|c|c|c|c|c|c|c|c|c|}
\hline & & 1 & 2 & 3 & 4 & 5 & 6 & 7 \\
\hline 1 & Philippine Bluefin Tuna D-loop & & & & & & & \\
\hline 2 & Thunnus orientalis & 0.034 & & & & & & \\
\hline 3 & Thunnus thynnus & 0.115 & 0.117 & & & & & \\
\hline 4 & Thunnus alalunga & 0.112 & 0.111 & 0.108 & & & & \\
\hline 5 & Thunnus maccoyii & 0.155 & 0.147 & 0.128 & 0.155 & & & \\
\hline 6 & Thunnus obesus & 0.121 & 0.124 & 0.108 & 0.134 & 0.099 & & \\
\hline 7 & Katsuwonus pelamis & 0.333 & 0.338 & 0.355 & 0.363 & 0.339 & 0.329 & \\
\hline
\end{tabular}


Table 2 Average pairwise genetic distances between CO1 sequences of Philippine Bluefin tuna and reference species

\begin{tabular}{llllllll}
\hline & 1 & 2 & 3 & 4 & 5 \\
\hline 1 & Philippine Bluefin Tuna CO1 & & & & & \\
3 & Thunnus orientalis & 0.000 & & & & \\
4 & Thunnus alalunga & 0.002 & 0.002 & & & & \\
5 & Thunnus thynnus & 0.016 & 0.016 & 0.014 & & 0.013 & 0.009 \\
6 & Thunnus maccoyii & 0.016 & 0.016 & 0.014 & 0.011 & 0.030 & 0.029 \\
7 & Thunnus obesus & 0.019 & 0.019 & 0.017 & & & \\
\hline
\end{tabular}

\section{Additional file}

Additional file 1: Supplementary data. (PDF $371 \mathrm{~kb}$ )

\section{Acknowledgements}

Authors would like to acknowledge BFAR and its management which provided the samples as a result of the livelihood projects on Fish Aggregating Device (FAD) granted for the fisher folks of Quezon Province. The authors thank: M/V DA-BFAR; BFAR-National Marine Fisheries Development Center (BFAR-NMFDC), particularly its staff and fisheries observer, Mr. Ruben Buemia Jr. who have given the necessary details of fishing operation and boat particulars; Mr. John Paul Maglantay who provided the photos; and to Undersecretary Asis Perez of the Department of Agriculture and Interim Executive Director Drusila Esther E. Bayate of NFRDI for the support. The authors also acknowledge the NFRDI for providing the necessary funding for the study which is under the project FISHCODES: DNA barcoding services in support of the development and implementation of fisheries management plans.

\section{Availability of supporting data}

The data sets supporting the results of this article are available in the Open Inter-university Consortium for Political and Social Research (OPENICPSR) repository, http://doi.org/10.3886/E56413V1.

\section{Authors' contributions}

KS carried out the molecular genetic studies, participated in the sequence alignment, and drafted the manuscript. MV helped in data analysisand helped drafting and revision of the manuscript. RR participated in sample collection. WDC helped in coordination with fishermen and data gathering MS conceived the study, participated in its design and coordination, and structured the writing of the manuscript. All authors read and approved the final manuscript.

\section{Competing interests}

The authors declare that they have no competing interests.

\section{Author details}

${ }^{1}$ Genetic Fingerprinting Laboratory, National Fisheries Research and Development Institute, Room 601 Corporate 101 Bldg, Mother Ignacia Avenue, Quezon City 1103, Philippines. ²Bureau of Fisheries and Aquatic Resources, PCA Building, Elliptical Road, Diliman, Quezon City, Philippines. ${ }^{3}$ National Marine Fisheries Development Center of the Bureau of Fisheries and Aquatic Resources, PCA Building, Elliptical Road, Diliman, Quezon City, Philippines.

Received: 24 November 2015 Accepted: 17 March 2016

Published online: 25 May 2016

\section{References}

Ashida H, Suzuki N, Tanabe T, Suzuki N, Aonuma E. Reproductive condition, batch fecundity, and spawning fraction of large Pacific bluefin tuna Thunnus orientalis landed at Ishigaki Island, Okinawa, Japan. Environ Biol Fish. 2015;98:1173-83.
Collette B., Fox W., Juan Jorda M., Nelson R., Pollard D., Suzuki N., Teo S. Thunnus orientalis. The IUCN Red List of Threatened Species 2014: e.T170341A65166749. http://dx.doi.org/10.2305/IUCN.UK.2014-3.RLTS.T170341A65166749.en. Downloaded on 29 October 2015.

Felsenstein J. Confidence limits on phylogenies: An approach using the bootstrap. Evolution. 1985:39:783-91.

Hillis DM, Bull JJ. An empirical test if bootstrapping as a method for assessing confidence in phylogenetic analysis. Syst Biol. 1993;42(2):182-92.

Itoh T, Tsuji S, Nitta A. Migration patterns of young Pacific bluefin tuna (Thunnus orientalis) determined with archival tags. Fish Bull. 2003:101:514-34.

Ivanova NV, Zemlak TS, Hanner RH, Hebert PDN. Universal primer cocktails for fish DNA barcoding. Mole Ecol Note. 2007;7(4):544-8.

Kimura M. A simple method for estimating evolutionary rate of base substitutions through comparative studies of nucleotide sequences. J Mol Evol. 1980;16:111-20.

Kunal SP, Kumar G, Menezes MR, Meena MM. Mitochondrial DNA analysis reveals three stocks of yellowfin tuna Thunnus albacares (Bonnaterre, 1788) in Indian waters. Conserv Genet. 2013;14(1):205-13.

Lewis AD. Conservation Management and Measures (CMM) Report on CMM 2010-04 (Pacific Bluefin Tuna). Western and Central Pacific Fisheries Commission. Northern Committee Eighth Regular Session. 3-6 September 2012. Nagasaki, Japan. 2012.

Paine MA, McDowell JR, Graves JE. Specific identification of Western Atlantic Ocean scombrids using mitochondrial DNA cytochrome c oxidase subunit I (COI) gene region sequences. Bull Mar Sci. 2007;80(2):353-67.

Pedrosa Gerasmio IR, Babaran RP, Santos MD. Discrimination of juvenile yellowfin (Thunnus albacares) and Bigeye (T. obesus) tunas using Mitochondrial DNA Control Region and liver morphology. PLoS One. 2012;7(4):e35604.

Saitou N, Nei M. The neighbor-joining method: A new method for reconstructing phylogenetic trees. Mol Biol Evol. 1987;4:406-25.

Santos MD, Lopez GV, Barut NC. A pilot study on the genetic variation of Eastern little tuna (Euthynnus affinis) in Southeast Asia. Philippine J Sci. 2010;139(1):43-50

Tamura K. Estimation of the number of nucleotide substitutions when there are strong transition-transversion and G + C-content biases. Mol Biol Evol. 1992; 9:678-87.

Tamura K, Stecher G, Peterson D, Filipski A, Kumar S. MEGA6: Molecular evolutionary genetics analysis version 6.0. Mol Biol Evol. 2013;30:2725-9.

Tanaka Y, Satoh K, Iwahashi M, Yamada H. Growth-dependent recruitment of Pacific bluefin tuna Thunnus orientalis in the northwestern Pacific Ocean. Marine Ecol Press Series. 2006;319:225-35.

Temminck CJ, Schlegel H. Pisces. In: Fauna Japonica, sive descriptio animalium quae in itinere per Japoniam suscepto annis 1823-30 collegit, notis observationibus et adumbrationibus illustravit P. F. de Siebold. 1843;5(6):73-112.

Viñas J, Tudela S. A validated methodology for genetic identification of tuna species (Genus Thunnus). PLoS One. 2009:4(10):e7606.

Volpe JP. Dollars without Sense: The Bait for Big-Money Tuna Ranching around the World. Bioscience. 2005;55(4):301-2.

Ward RD, Zemlak TS, Innes BH, Last PR, Hebert PDN. DNA barcoding Australia's fish species. Philos Trans R Soc B. 2005:360:1847-57. 